\title{
Correspondence
}

\section{Private Race Preferences in Family Formation}

\author{
R. Richard Banks, The Color of Desire: Fulfilling Adoptive Parents' Racial \\ Preferences Through Discriminatory State Action, 107 YALE L.J. 875 (1998).
}

Elizabeth Bartholet ${ }^{\dagger}$

Richard Banks's article The Color of Desire questions whether private racial preferences for same-race children, and state agency practices accommodating and encouraging such preferences, should be accepted as legitimate. Why are so many people so ready to assume that it is natural, and appropriate, to think in racial terms in the intimate family context? I agree with Banks that it is important to question this assumption. I agree that there is a connection between these private racial preferences and the public racial preferences that are generally condemned as "discrimination." I agree that private racial preferences are not inherent, unalterable conditions of humankind, but rather products of our social conditioning. And I agree with Banks that it would be good to take steps to change the way people think about race in the family context. This is an important part of why I have long advocated elimination of state-imposed barriers to transracial adoption, ${ }^{2}$ and why I have argued that the state should not exercise any preference whatsoever for placing children with racially matched families. ${ }^{3}$ Such policies not only prevent the formation of transracial families, but also condition people to think badly of racial intimacy.

$\dagger$ Professor of Law, Harvard Law School.

1. R. Richard Banks, The Color of Desire: Fulfilling Adoptive Parents' Racial Preferences Through Discriminatory State Action, 107 Y ALE L.J. 875 (1998).

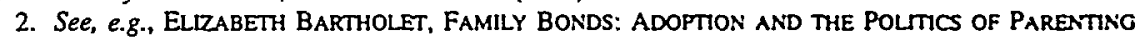
86-117 (1993); Elizabeth Bartholet, Race Separatism in the Family: More on the Transracial Adoption Debate, 2 DUKE J. GENDER L. \& POL'Y 99 (1995); Elizabeth Bartholet. Where Do Black Children Belong? The Politics of Race Matching in Adoption, 139 U. PA. L. REv. 1163 (1991) (heresnafter Bartholet, Where Do Black Children Belong?].

3. See, e.g., Bartholet, Where Do Black Children Belong?, supra note 2. at 1251-52. 
But if we are to think seriously about the problem of racial preferences in the intimate family context, we need to look at the arenas in which these preferences are operating most significantly ${ }^{4}$ and to address decisions about romantic and sexual relationships, marriage, traditional procreation, and the production of children through reproductive technology and surrogacy arrangements.

Banks's article focuses on an oddly limited part of the relevant terrain: private preferences in adoption only, and only as facilitated by the state. Private preferences, however, are conditioned by public policy in the entire family-decisionmaking arena, not simply in adoption. Public policy encourages the creation of same-race families by a multitude of laws and practices. For example, states "facilitate" private race preference when they license marriage partners without inquiry into the role race played in partner selection. Our society encourages racially matched parenting through employment and health insurance policies that subsidize procreation, through constitutional doctrines that protect the "right" to procreate, through free market policies that allow the purchase and sale of sperm, eggs, embryos, and surrogacy services, and through social conditioning that puts a high value on parenting genetically related children. At the same time, our society discourages adoption through restrictive regulation, making adoption expensive while failing to provide the financial subsidies that we accord procreation, and stigmatizing adoption as a second-class form of parenting. And in discouraging adoption, we discourage transracial families, because the children in need of adoptive homes here and abroad are, overwhelmingly, non-Caucasian, and the adults seeking to become adoptive parents are, overwhelmingly, Caucasian.

By trying to force a fit between his racial theory and the transracial adoption debate, Banks mischaracterizes both the nature of that debate and the nature of the problem facing black children. He describes the debate as if it involved a group of whites defending transracial adoption and facilitative accommodation arrayed against a group of blacks defending race matching. He portrays the white position as based on a classic liberal conception of the autonomous individual, and as placing greater value on the white parent's autonomy interests than on the black child's equality interests. ${ }^{5} \mathrm{He}$ claims that the white position promotes white group interests while the black position promotes black group interests, ${ }^{6}$ although he says the white position is purportedly race blind.

But black and white groups and interests do not stack up so neatly in this debate. There is enormous support among whites, especially those in the child welfare system, for race matching. At the same time, polls demonstrate very

4. See Randall KenNedy, Racial REgulation of Intimate association: SEx, Marriage and ADOPTION (forthcoming 1998).

5. See, e.g., Banks, supra note 1 , at $895,914$.

6. See id. at $922-28$. 
little support among blacks in the general population for the National Black Social Workers Association's position supporting race matching. 'And leading black intellectuals have joined with whites in challenging race-matching policies. ${ }^{8}$ Moreover, commitment to adult autonomy and race-blind theory does not characterize my position or that of many who have been outspoken in opposing race matching. ${ }^{9}$

Banks finds it an "anomaly" that those of us opposing state-imposed barriers to transracial adoption have not addressed the issue of "facilitative accommodation," 10 as though we were not aware that the phenomenon exists. Of course it exists, and of course it could be legally challenged. The issue for me, however, is whether it would be a good idea to try to eliminate private preferences with the coercive measures that Banks suggests. I agree that the state should take no action to encourage the exercise of private racial preference. But Banks goes further, arguing that the state should not allow prospective adopters to consider race.

Here I disagree with Banks. I do place some value on autonomy, and do not think the state should get in the business of limiting choice in marriage, procreation, or adoptive relationships, ${ }^{11}$ unless absolutely necessary. And although I think that it would be good for more people to cross racial and other lines of difference in the formation of their families, I do not think that it is so clearly bad if many others form families on the basis of similarities in racial, religious, ethnic, and national heritage. Banks argues that his proposals will help alleviate the plight of many African-American children now held for long periods in foster care. ${ }^{12}$ I fear that if his proposed system were ever implemented it might hurt the life chances of the very children he wants to help.

In reforming the role race plays in adoption, the logical place to start is with the elimination of state-imposed barriers to transracial adoption. Banks writes as if this problem had been solved with the passage of the Multiethnic Placement Act and Interethnic Adoption Provisions collectively known as

7. See Bartholet, Where Do Black Chuldren Belong?, supra notc 2. at 1236 n 206. id. at $1179-80$

8. See, e.g., Kim Fonde-Mazni, Black Identty and Chid Placement. The Best Interesis of Black and Biracial Children, 92 MICH. L. REV. 925 (1994): Ezra E.H. Gnffith. Culture and the Debuse on Adoption of Black Children by White Families, 14 AM. PSYCHIATRIC PRESS REV PSYCIIATRY 543 (1995), Randall Kennedy, My Race Problem-And Ours. ATLANTIC MONThLY. May 1997, al 55 (questionng the value of "racial pride" and "racial kinship").

9. See, e.g., Bartholet, Where Do Black Chuldren Belong”. supra note 2, at 1226-56, Jaan Heiferz Hollinger, Responses io Where Do Black Children Belong. RECONSTRLCTIoN, 1992 No 4. at 48. 49.51. Laurence H. Tribe, Trans-Racial Adoption, RECONSTRLCTION, 1992 No.l, at 105

10. E.g., Banks, supra note 1, at 882 n.24, 887, 914 .

11. Our legal system has traditionally placed a high value on autonomy in the procreation context, but not in the adoption context. I do not, however, find the distunction made between these two ways of forming a parental relationship appropriate. See BARTHOLET, supra note 2. at 76-78

12. See Banks, supra note 1 , at 927. 
MEPA. ${ }^{13}$ He claims that the nature of the current debate "virtually guarantees a move away from race matching." $" 14$ Would that it were so. Federal law has prohibited the use of race to delay or deny adoptive placement since $1994,{ }^{15}$ and the 1996 amendments eliminated a provision that had allowed race to be a "permissible consideration,"16 creating a new regime in which federally funded agencies are not allowed to use race at all in making foster and adoptive placement decisions. But there is enormous resistance to this law, and it appears so far to have had little impact. ${ }^{17}$ State social service agencies tend to be committed from top to bottom to their race-matching ways. Private foundations and nonprofit child welfare groups have joined forces with public agencies to promote "kinship care,"18 in part to help ensure that children in need of homes remain within their racial group. "Cultural competence" is one of the code phrases in the post-MEPA era for assessing whether agencies remain sufficiently committed to same-race matching and whether they are doing enough to recruit families of color to make same-race placement possible. The U.S. Department of Health and Human Services, responsible for enforcing MEPA, is peopled with child welfare traditionalists imbued with the race-matching ideology, and has done little to date to ensure that federally funded state adoption agencies live up to MEPA's mandate. MEPA may someday have a significant impact but, for now, race matching by the state is alive and well.

Because state-imposed racial barriers remain the order of the day, there is no way of knowing how much of a problem private race preferences would pose if those barriers were actually eliminated. Banks purports to describe a world in which private preferences are operating to deny black children adoption opportunities, but this is a hypothetical world. We do not know whether private preferences would have a significant negative impact on black children's adoption opportunities if state-imposed barriers that now exist were eliminated. We do know, however, that a significant percentage of prospective adopters on public agency waiting lists show an interest in adopting across

13. See id. at $900 \&$ n.105 (discussing the Multiethnic Placement Act, 42 U.S.C.A. $\$ 1996$ b (West Supp. 1997)).

14. Id. at 927.

15. See Howand M. Metzenbaum Multiethnic Placement Act of 1994, Pub. L. No. 103-382, §§ 551554, 108 Stat. 4056, 4056-57 (codified as amended at 42 U.S.C.A. $\$ 1996 \mathrm{~b}$ ).

16. See Small Business Job Protection Act of 1996, Pub. L. No. 104-108, § 1808(c), 110 Stat. 1755 , 1904 (codified at 42 U.S.C.A. \$1996b).

17. I have been actively involved for over a decade in research, writing, and advocacy related to race and adoption issues including, more recently, work designed to assess MEPA's impact and to promote its implementation. I base the claims in this paragraph on this ongoing work and on Telephone Interview with Joan Hollinger, Visiting Professor of Law, University of California at Berkeley, and Member, Permanency Guidelines Expert Work Group, Interagency Initiative of the U.S. Department of Justice and the U.S. Department of Health and Human Services (Mar. 4, 1998); and Telephone Interview with Richard Barth, Director, Center for Social Services Research, University of California at Berkeley (Mar. 5, 1998).

18. Kinship care involves the placement of children by state agencies with relatives for purposes of foster care, adoption, or guardianship. 
racial lines. ${ }^{19}$ We also know that in the private agency world, where state barriers do not exist, many transracial adoptions take place and black children are generally placed promptly. ${ }^{20}$ We might, therefore, very well solve the problems of the black children in foster care waiting for adoptive homes ${ }^{21}$ by simply implementing MEPA's mandate and eliminating state-imposed racial barriers.

Banks's "strict nonaccommodation"22 would risk making things yet harder on the children in foster and institutional care who need adoptive homes. What would it mean for children awaiting adoption to be considered individually, rather than being excluded categorically, by prospective parents who do not want a child of another race? Most children awaiting adoption are old enough to realize that they are being considered for adoption by the adults invited to meet them individually or in groups. ${ }^{23}$ Most of them have already been overwhelmingly battered by life. Many are born damaged as a result of alcohol and drug use by their mothers. Most suffer serious abuse or neglect before entering foster care, and then years of institutional abuse and neglect as they bounce from foster home to biological home and back again, or from one foster home to another. Once these children are finally freed for adoption, do we want to put them through more sessions of individual rejection than we need to? Do we want to put pressure on prospective parents to adopt a black child, even if they do not wish to do so?

Banks recognizes that his proposal might drive many prospective adopters from the public adoption system into the private agency and independent adoption worlds, where two-thirds of all adoptions already take place. ${ }^{3:}$ But he argues that those who will exit will be white prospective adopters without any interest in adopting transracially and that therefore no harm will follow to the black children waiting to be adopted, or to the white children for whom he claims there is an overabundance of waiting white parents. ${ }^{35}$ I think Banks

19. See James Breay, OffCe of Field Support Servs.. Massachlisetts Dep't of Social Servs., WHO ARE THE WAITING CHILDREN? tbl.3.3 (1991) (reporting that approximately one-sixth of waung white families are interested in adopting minority race children).

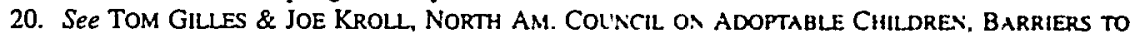
SAME RACE PLACEMENT 8, 9, 16, 20-21 (1991) (finding a significanily higher rate of transracial placement in private, as compared to public, agencies). This is part of why so many black birth parents choose to place their children for adoption in the private rather than the public adoption system See Bartholet, Where Do Black Children Belong?, supra note 2, at 1234.

21. See Banks, supra note 1, at 888 n.42 (noting that "all avalable data suggests that black chıldren are both less likely to be adopted than white children and likely to spend a longer ume waung to be adopted").

22. Id. at 940; see also id. at 940-63 (discussing the idea of stnct nonaccommodation)

23. For a discussion of the characteristics of the children awating adoption discussed in this paragraph. see generally JILL DUERR BERRICK ET AL., BAY AREA SOC. SERVS CONSORTILM. FACTORS ASSOCIATED WITH FAMILY REUNIFICATION OUTCOMES: UNDERSTANDING REEITRY TO CARE FOR INFANTS (1997); and Carol StatuTO BEVAN, National COUNCIL FOR ADOPTION, FOSTER CARE. TOO MILCH TOO LITTLE TOO EARLY TOO LATE (1996).

24. See Banks, supra note 1 , at $956-58$.

25. See id. at 957-58. 
is wrong on both counts. First, many prospective parents who might be interested in children of another race, if given the chance to think about it, will simply refuse to enter the public adoption system if it limits their choices even more drastically than does today's system. Second, given the terrible damage, both psychological and physical, suffered by many children in foster and institutional care, we need an overabundance of prospective adopters in order to have a chance of finding the needed homes.

If we want to help black children in foster care, we should start by enforcing MEPA so as to take the state out of the business of promoting racially matched families. There are many steps beyond enforcing MEPA that would be both more effective and less intrusive than Banks's proposed course of action. For example, we could expand the law to cover private agencies, as suggested by the proposed Uniform Adoption Act, ${ }^{26}$ since most private agencies engage in race matching, even if less insistently than public agencies. ${ }^{27}$ In addition, instead of recruiting adoptive families for waiting children on a same-race basis, as state agencies now do, ${ }^{28}$ we could cast the recruitment net much more widely, encouraging black and white families alike to consider adoption and to consider crossing the racial line. In the current regime, social workers often question the emotional stability of prospective parents who express an interest in transracial adoption. We should instead socialize prospective parents to think positively about transracial parenting.

Our public adoption system already drives away many prospective adopters, black and white, by virtue of its negative, restrictive, bureaucratized nature. They flee to the private adoption world where, along with children and birth mothers', they are treated much better. In that private world, many seek to adopt on a same-race basis, but many others adopt across racial lines. Yet others go abroad for international adoption where they typically adopt across a variety of lines of difference-racial, ethnic, religious, and national. We should be drawing prospective parents into our public adoption system, not driving them away, if we want to advance the goals that Banks and I share: improved life prospects for black children and a different understanding of the role race should play in our private lives.

26. See UNIF. ADOPTION ACT $\S 2-104$ (c) \& cmt., 9 U.L.A. 16 (Supp. 1996).

27. See GILLES \& KROLL, supra note 20 , passim.

28. See Bartholet, Where Do Black Children Belong?, supra note 2, at 1196-97; Elizabeth Bartholet, More Than Ever, State Should Cast Wide Net in Search of Foster Parents, Boston GLOBE, Apr. 14, 1997, at All. 


\title{
A Response to Elizabeth Bartholet
}

\author{
R. Richard Banks ${ }^{\dagger}$
}

Professor Bartholet's correspondence is provocative and thoughtful. We share a concern about the diminished pool of adoptive parents available to black children, and we are both adamantly opposed to race matching by adoption agency personnel. Bartholet, however, would permit race matching by adoptive parents, whereas I would not.' I chose to write about what Bartholet describes as an "oddly limited part of the relevant terrain"" because the particular characteristics of the adoption process offer a unique opportunity to illustrate the ways in which private racial preferences, state policy, and perceptual biases combine to produce widespread inequality that persists in part because of our inability to "see" it.

Bartholet is equivocal about two facts that should not be in dispute. First, she mischaracterizes both her work and the broader debate by stating that "[o]f course [facilitative accommodation] exists, and of course it could be legally challenged." 3 Of course? Facilitative accommodation, which affects in excess of 100,000 parents and children every year, ${ }^{4}$ has not previously been identified as a significant aspect of adoption policy, much less as race-based state action. My article investigated this omission. More importantly, private racial preferences produce widespread inequality in adoption, a circumstance Bartholet describes as "hypothetical." In fact, however, preference-produced inequality is so ingrained in accepted adoption practices and outcomes that we scarcely notice it.

In addition, Bartholet overstates the proportion of white parents willing to adopt a black child. The study she cites ${ }^{6}$ presents a classic sample selection

Assistant Professor of Law, Stanford Law School.

1. I am fully aware that race matching continues, in spite of the Multiethnic Placement Act (MEPA). 42 U.S.C.A. § 1996b (West Supp. 1997). Nonetheless, the passage of MEPA does represent a move away from race matching. Bartholet does not consider the possibility that strict nonaccommodalion. by prohibuting all racial recordkeeping in adoption, might make it more possible to implement MEPA effoctuvely. Striet nonaccommodation is wholly compatible with ending race matching.

2. Elizabeth Bartholet, Private Race Preferences in Family Formarion, 107 Y ALE LU. 2351. 2352 (1998) (correspondence).

3. Bartholet, supra note 2, at 2353.

4. See R. Richard Banks. The Color of Desire: Fulfilling Adopuve Parenis' Racial Preferences Through Discriminatory State Action, 107 YALE L.J. 875, 878 \& n.6 (1998).

5. Bartholet, supra note 2, at 2354.

6. See id. at 5 n. 19 (citing JAMES BREAY, OFFCE OF FIELD SUPPORT SERVS. MASSAChusetTS DeP'T OF SOCIAL SERVS., Who ARE THE WATTING CHILDREN? (bl.3.3 (1991)). 
problem. ${ }^{7}$ Moreover, the study's focus on parents' stated willingness to adopt a "racial minority" child ${ }^{8}$ elides the fact that white parents are significantly more inclined to adopt a nonblack racial minority child than a black child." Finally, the study itself found that parents were two to three times more likely to consider adopting a sibling group or a disabled child than a single racial minority child. ${ }^{10}$

To think seriously about racial inequality in adoption, however, requires that we move beyond a narrow focus on adoption rates. Bartholet has previously identified as an adverse outcome of race matching the placement of black children, but not white children, with "economically marginal" or "less qualified" parents." Adoptive parents' racial preferences produce the same sort of inequality. Even the study that Bartholet cites indicates that, because of adoptive parents' preferences, any particular white child has access to a pool of adoptive parents at least two to three times as large as that available to any particular black child. ${ }^{12}$ Does Professor Bartholet seriously contend that this state of affairs does not evidence racial inequality?

Bartholet and I both acknowledge that the adverse, unintended consequences of strict nonaccommodation may outweigh its benefits, ${ }^{13}$ in which case we should certainly not implement the policy. We should be mindful, however, of the risks of "protecting" children by deferring to the very attitudes and practices that harm them. A decision to forgo strict nonaccommodation should be viewed not as an example of sensibly practical policy analysis, but as a tragic capitulation to private racial preferences emblematic of the race-based thinking that threatens to corrupt American democracy.

My article proposed a solution to racial inequality in adoption in part to direct attention to the analytically prior step of reframing a broader social problem. That preferences are difficult to challenge directly does not mean that they are not a problem. To the contrary, they are a problem of such magnitude that they limit the scope of the remedies we might consider.

7. The study involved only parents seeking to adopt children under the care of the Department of Social Services in politically liberal Massachusetts. Because a much higher proportion of nonwhite children are served through the Department than through private agencies, see Banks, supra note 4, at 898 , the white parents adopting through that route are likely to be much more racially open-minded than their non-childwelfare-agency counterparts. Otherwise, they would not be adopting through the public agency process.

8. BREAY, supra note 6 , at tbl.3.3.

9. See D. Brooks \& R.P. Barth, Preferred Characteristics of Children in Need of Adoption Services: A Comparison of Public/Private Agency and Independent Adopters and Workers' Responses to Expressed Preferences for African American Children 3 tbl.1 (1995) (unpublished manuscript, on file with the Yale Law Joumal).

10. See BREAY, supra note 6, at tbl.3.3.

11. Elizabeth Bartholet, Where Do Black Children Belong? The Politics of Race Matching in Adoption, 139 U. PA. L. REV. 1163, 1199-200 (1991).

12. See BREAY, supra note 6, at tbl.3.3.

13. See Banks, supra note 4, at 955-58 (discussing the potential drawbacks of strict nonaccommodation). 